\title{
CARDIOGENIC SHOCK INDUCED BY A HIGH DOSE OF INTRAVENOUS MORPHINE
}

\author{
ŁUKASZ SEIN ANAND ${ }^{1,2}$, PAWEŁ KONSTANTY KOROLKIEWICZ ${ }^{1}$, and JACEK SEIN ANAND ${ }^{1,2}$ \\ ${ }^{1}$ Medical University of Gdansk, Gdańsk, Poland \\ Department of Clinical Toxicology \\ ${ }^{2}$ Pomeranian Center of Toxicology, Gdańsk, Poland
}

\begin{abstract}
Morphine is an opiate alkaloid characterized by various clinical effects, among which the most prominent are its analgesic and psychoactive effects. It also has a prominent depressive effect on the respiratory and cardiovascular system. Because of its psychoactive effect, morphine is very addictive and often used as a recreational narcotic. As a medication, it has found its use as an analgesic agent in chronic pain treatment, in hemorrhagic shock, and in acute heart failure with pulmonary edema. Albeit, morphine use in heart failure is controversial, based on many observational studies showing the negative effect on the outcomes of the patients treated with morphine during acute cardiovascular incidents. In this report, the authors present a case of cardiogenic shock (CS) with transient left ventricular ejection fraction reduction, occurring in a patient attempting suicide using a high dose of intravenous morphine sulphate administration. Other CS causes were ruled out. To the best of the authors' knowledge, this is the second case of a morphine-related CS reported in literature. Int J Occup Med Environ Health. 2021;34(1):133-8
\end{abstract}

Key words:

suicide, toxicology, opioids, cardiogenic shock, pharmacology, morphine

\section{INTRODUCTION}

Morphine is an opiate alkaloid, derivative of phenanthrene, characterized by a strong analgesic, anti-diarrheal, anti-cough and psychoactive effect [1,2]. The mechanism of morphine activity is based upon the agonistic effect on 3 different classes of opioid receptors: mu, kappa and delta, present in the central nervous system, the peripheral nervous system, internal organs and blood vessels. Among the various clinical effects of morphine, the most prominent are: miosis, constipation, nausea and vomiting, anuria, common bile duct constriction, euphoria, dysphoria, agitation, anorexia and xerostomia. It also has a strong depressive effect on the central nervous, respiratory, and cardiovascular systems [3]. Because of its potent and highly addictive psychoactive effect, it is often used as a recreational narcotic [4].

Morphine can be administered orally, intravenously, subcutaneously, in transdermal form or by inhalation [5]. It is widely used as a medication, most often in chronic pain treatment [5], hemorrhagic shock [6], or acute heart failure accompanied by pulmonary edema with severe dyspnea [7]. Although it is clear that the therapeutic use of morphine has many positive effects, there are studies that bring up concerns about serious side effects and risks associated with its use, such as reported a higher mortality among the patients treated with morphine in acute heart failure or with acute coronary syndromes [7-11].

Received: March 22, 2020. Accepted: October 2, 2020.

Corresponding author: Łukasz Sein Anand, Medical University of Gdansk, Department of Clinical Toxicology, Kartuska 4/6, 80-104 Gdańsk, Poland (e-mail: lsanand@gumed.edu.pl). 
In this study, the authors describe a case of cardiogenic shock (CS) occurring in a young male, mixed-martial arts practitioner, without a previous history of cardiovascular events and heart disease, after suicidal intravenous administration of high doses of morphine.

To the best of the authors' knowledge, this is the second case of a morphine-related CS reported in literature [12].

\section{CASE REPORT}

A 35-year-old man was admitted to the Regional Toxicology Centre (RTC) because of suspected suicidal intravenous morphine administration. The patient was found by paramedics at his house, unconscious, with a peripheral venous catheter in his left upper extremity and empty packets of the morphine drug preparation lying around him.

Because of severe bradypnea (4 breaths/min), the paramedics administered intravenously $0.4 \mathrm{mg}$ of naloxone, which resulted in a faster breath rhythm (10 breaths/min) and a lessening of the coma severity.

The blood test conducted in the emergency department brought up elevated leukocyte count $\left(19.4 * 10^{9} /\right.$; normal range: $4.0-11.0 * 10 \%$ ), creatinine kinase (473 U/l; normal value: <200 U/l), creatine $(192 \mu \mathrm{mol} / \mathrm{l}$; normal range: $50-110 \mu \mathrm{mol} / \mathrm{l})$ and potassium $(5.43 \mathrm{mmol} / \mathrm{l}$; normal range: $3.5-5.0 \mathrm{mmol} / \mathrm{l})$. The urine drug testing using immunoassay turned up positive for opiates and benzodiazepines. Because of the acute respiratory insufficiency in a form of an increase in the partial pressure of carbon dioxide of $>55 \mathrm{~mm} \mathrm{Hg}$, blood oxygen saturation of $<80 \%$, breath rhythm of $<8$ breaths/min, and no response to a $0.8 \mathrm{mg}$ bolus of naloxone, the patient was intubated and mechanically ventilated. Because of severe hypotension (70-80/30-40 mm Hg), a crystalloid solution was administered intravenously with a good clinical effect. After 3-4 h of such therapy, the patient regained consciousness and could follow simple instructions.

After a successful weaning test (the Rapid Shallow Breathing Index of $<80$ breaths/min/l), the patient was extubated without complications. To maintain the correct blood oxygen saturation, the patient needed a passive oxygen therapy with a face mask. Periodic bradypnea and drowsiness were successfully managed with naloxone infusion $(0.2 \mathrm{mg} / \mathrm{h}$, for $5 \mathrm{~h})$. Because of the positive urine screening for benzodiazepines, an additional infusion of flumazenil $(0.1 \mathrm{mg} / \mathrm{h}$, for $5 \mathrm{~h})$ was administered.

In the next few hours of the therapy, a sudden severe hypotension $(<60 / 40 \mathrm{~mm} \mathrm{Hg}$ ) occurred, with no response to the fluid therapy and the naloxone infusion $(0.2-0.4 \mathrm{mg} / \mathrm{h})$. Using a norepinephrine infusion $(0.01 \mu \mathrm{g} / \mathrm{kg} / \mathrm{min}$ up to $0.09 \mu \mathrm{g} / \mathrm{kg} / \mathrm{min}$ ), the arterial pressure was maintained at $92 / 45 \mathrm{~mm} \mathrm{Hg}$ with a steady heart rate of 69 beats/min. In the point-of-care ultrasound examination of the lungs, heart and abdomen, the enlargement of the right heart and a disorder of the interventricular septum contractility were found.

The electrocardiogram (ECG) revealed regular heart rhythm with no abnormalities seen on the ECG curve.

The blood testing revealed increased $\mathrm{N}$-terminal pro B-type natriuretic peptide (NT-Pro-BNP) $(2530 \mathrm{pg} / \mathrm{ml}$; normal value $<450 \mathrm{pg} / \mathrm{ml}$ ), cardiac troponin T-high sensitive (387 ng/l; normal value <14 ng/l) and creatine kinase-isoenzyme MB mass ( $29.83 \mathrm{ng} / \mathrm{ml}$; normal value $<4.9 \mathrm{ng} / \mathrm{ml}$ ), which suggested myocardial damage and congestive heart failure.

Full echocardiographic examination revealed signs of the volumetric overload of the right ventricle and ventricular dyssynchrony, with left ventricle ejection fraction (LVEF) calculated as $30 \%$.

Thromboembolism was ruled out as a reason for the right ventricle overload using computed tomography angiography.

In the next $48 \mathrm{~h}$ of the treatment, the patient needed continuous norepinephrine infusion, after which the hypotension gradually subsided. In the second echocardiographic examination done after 2 days of the therapy, there were no signs of the previous overload and dyssynchrony, and LVEF had risen to $>65 \%$. 
The blood test revealed the lowering of NT-Pro-BNP to the normal range. Prothrombin time, the international normalized ratio and activated partial thromboplastin time were within the normal ranges throughout the hospitalization.

After hemodynamic stabilization, the patient confessed to the suicidal character of the poisoning. He reported that he had taken 120 tablets (20 mg of morphine sulphate each) of the morphine drug preparation, dissolved it in 0.51 of still water, and administered the solution intravenously.

During the examination, it turned out that the patient had been hospitalized in the RTC about 2 years prior to the current admission, because of a suicidal intravenous administration of morphine and midazolam. At the time, the patient was burdened with acute respiratory insufficiency that needed mechanical ventilation; however, there were no signs of CS presence. The patient also reported that he suffered from Perthes disease. Because of that, he had been prescribed morphine as an analgesic, which he had been abusing for about 11 years.

\section{DISCUSSION}

Cardiogenic shock is defined as a lowering of the systolic blood pressure $<90 \mathrm{~mm} \mathrm{Hg}$, or a sudden lowering of at least $60 \mathrm{~mm} \mathrm{Hg}$, with adequate vascular bed filling and present signs of hypoperfusion [7]. Among the most common causes of CS are direct heart muscle damage caused by ischemia or infarction, myocarditis, valvular heart diseases and stress cardiomyopathy [13]. Although there are many novel methods of the therapy, the intrahospital mortality of CS is still very high and goes $>40 \%$ of the admitted cases $[14,15]$.

To the best of the authors' knowledge, the case described in this publication is the second documented case of $\mathrm{CS}$ related to the acute morphine poisoning. It is worth mentioning that in both this and the first reported case, the other causes of CS were ruled out.

The first published case of the CS induced by morphine was a case of a 47-year-old woman, who had been admin- istering intravenous morphine in a form of a patient-controlled analgesia because of a severe pain accompanying acute pancreatitis. After administering herself $47 \mathrm{mg}$ of morphine in a span of $12 \mathrm{~h}$, the woman lost consciousness and presented severe hypotension $(73 / 38 \mathrm{~mm} \mathrm{Hg})$ with signs of hypoxia. The administration of the naloxone infusion lessened the respiratory insufficiency and severity of the coma in that patient, with no apparent effect on hypotension, which stabilized only after an additional norepinephrine infusion. After $5 \mathrm{~h}$ of the norepinephrine infusion, the patient became hemodynamically stable [16]. It is worth mentioning that in both this case and that presented by Feeney et al. [12], morphine was administered by the patients intravenously. After that, both cases presented a loss of consciousness and acute respiratory insufficiency, which were successfully managed with naloxone infusion and oxygen therapy. In both cases, there was a sudden occurrence of hypotension not responding to fluid therapy, which needed continuous norepinephrine infusion for stabilization. In both cases, a significant reduction in LVEF and the right ventricle overload was observed in the echocardiographic examination, these effects being transient in their nature and disappearing after treatment.

The most notable difference between those 2 cases was the administered dose. In the case reported by Feeney et al. [12], the patient administered herself $47 \mathrm{mg}$ of morphine over a period of $12 \mathrm{~h}$. In the case presented in this study, the patient administered himself about $2400 \mathrm{mg}$ of morphine in 1 bolus, which was over 50 times more than the dose of the patient discussed by Feeney et al. [12] Differences in the doses of that magnitude could have been at least a partial reason for the differences between the severity of the coma, the degree of respiratory insufficiency and the duration of hypotension $(5 \mathrm{~h}$ in the Feeney et al. [12] report as opposed to $48 \mathrm{~h}$ in the case of the patient discussed in this study).

It is also worth mentioning that the patient discussed by Feeney et al. was burdened with acute pancreatitis and 
hypertension, both of which could have been reasons for higher sensitivity to morphine, as opposed to this patient who had been abusing morphine for the past 11 years, resulting in a high tolerance to the opiates, and thus lower susceptibility to its effects. It is also interesting that during this patient's first suicide attempt using morphine, there were no signs of CS. The reason for this may be the difference in the morphine doses. At his first attempt, the patient administered about $1200 \mathrm{mg}$ of morphine, which was only half of the dose he used at his second attempt. In both attempts, he administered the same preparation in the form of tablets dissolved in still water.

In the case of this patient, there could also be an aggravating effect on the cardiovascular system by the dissolved tablets, not designed for parenteral use. As of now, there are studies reporting pulmonary hypertension and pulmonary embolization which are related to small insoluble particles of tablets congesting in small pulmonary vessels. Many of such cases are related to drug abuse [17]. The patient dissolved a high quantity of tablets which could have been one of the factors leading to an increase in pulmonary pressure and right ventricle overload.

The additional influence of the rate of morphine administration on CS cannot be ruled out, but because of highly different doses and the differences in susceptibility to morphine in both this patient and the patient discussed by Feeney et al., it is impossible to assess adequately such an effect.

As of now, there have been scarce data concerning such influence, mostly based on the publication describing how different rates of morphine infusions affect healthy populations. The study reports a significant effect of a higher infusion rate on enhancing the subjective perception of drug effects and the peak morphine plasma level, without any significant effect on both psychomotor impairment and physiological response [18]. It is worth mentioning that the doses used in the study were relatively low, so there is a possibility that in the case of higher doses frequently used in drug abuse or severe pain, the influence might be different.
At the moment, it is hard to explain the pathomechanism of a morphine-related CS. The incomplete knowledge about the effects of the activation of the different classes of opioid receptors on cardiac function, their exact localization throughout the heart, and also the need of referring mostly to either animal models or post-mortem heart examination, cause many contradictory results about the inotropic, chronotropic and dromotropic effects of opioids [16]. Concentrating on clinical studies, there is no less controversy than in experimental studies about opiates and their effects on the cardiovascular system.

On the one hand, there are speculations that the endogenic opioids, such as enkephalins, may have a cardioprotective effect during ischemic states by the stimulation of myocardial ischemic conditioning [19], the modulation of heart metabolism, diminishing the sympathetic effect of $\beta$-receptors and improving vagal response [16]. On the other hand, the vasodilatory and hypotensive effects of morphine have been proven [16], which play a crucial role in the pathomechanism of the shock. There are also studies proving that some opioids have a cardiotoxic effect, or may elongate the QTc interval, thus leading to an increase in the incidence of life-threatening arrhythmias, such as torsade de pointes [20-22].

Other than that, there is an observation made on an animal model that shows the aggravation of other drugs cardiotoxicity during the administration of morphine. The study reported that during the administration of doxorubicin, which has a cardiotoxic effect leading to the anthracyclineinduced cardiomyopathy, additional morphine administration aggravated the toxicity. The aggravating effect was not observed during an additional naloxone infusion, thus further supporting the claim [23].

This claim is especially important for patients suffering from neoplasia, who are often administered anthracycline-based chemotherapy alongside morphine-based analgesia.

Many animal models were used to prove that the endogenic opioid system plays an important role in the patho- 
physiology of the shock, cardiovascular insufficiency, and myocardial ischemia. Studies have also shown a negative effect of dynorphin (endogenous opioid) at the beginning of CS, and a protective effect of naloxone, which is an opioid antagonist, on that process. Moreover, naloxone seems to have a vasoconstrictive effect during the shock, further supporting the claim of the opioid role in shock pathogenesis [24].

There are also reported cases of CS occurring after the administration of opioids different from morphine, such as tramadol [25] or dextropropoxyphene [26].

Moreover, there is a widely observed effect on mortality of the patients treated with morphine during acute heart failure or acute coronary syndromes [7-11], but because of the lack of randomized clinical trials and observational characteristics of the conducted studies, it is impossible to draw definite conclusions on that subject. However, the guidelines of the European Cardiovascular Society report the suspected effect on mortality and recommend not to use morphine routinely in acute heart failure with an exception of cases with severe dyspnea and pulmonary edema [7].

\section{CONCLUSIONS}

The presented case shows that, in clinical practice, there is a possibility of CS with severe hypotension associated with morphine use. The administration of norepinephrine and the naloxone infusion seem to be sufficient to compensate for the hypotension, which subsides after some time. There is also a need for further research to determine the precise effects of morphine on the myocardium.

\section{REFERENCES}

1. Stefano GB, Ptáček R, Kuželová H, Kream RM. Endogenous morphine: up-to-date review 2011. Folia Biol (Praha). 2012;58(2):49-56.

2. Brownstein MJ. A brief history of opiates, opioid peptides, and opioid receptors. Proc Acad Sci. 1993;90(12):5391-3, https://doi.org/10.1073/pnas.90.12.5391.
3. Murphy PB. Morphine [Internet]. StatPearls. U.S. National Library of Medicine; 2019 [cited 2020 Aug 1]. Available from: https://www.ncbi.nlm.nih.gov/books/NBK526115/.

4. Listos J, Łupina M, Talarek S, Mazur A, Orzelska-Górka J, Kotlińska J. The mechanisms involved in morphine addiction: An overview. Int J Mol Sci. 2019;20(17), https://doi.org/ 10.3390/ijms20174302.

5. Dobrogowski J, Wordliczek J, Szczudlik A, Stępień A, Drobnik J, Leppert W, et al. Zasady stosowania silnie działających opioidów u pacjentów z bólem przewlekłym pochodzenia nienowotworowego - przegląd piśmiennictwa i zalecenia Polskiego Towarzystwa Badania Bólu, Polskiego Towarzystwa Neurologicznego i Polskiego Towarzystwa Medycyny Rodzinnej. Ból. 2015;16(3):9-29. Polish.

6. Charleston C, Puana R, McAllister RK, Hunter FA, Childs EW. Morphine Sulfate Attenuates Hemorrhagic Shock-Induced Hyperpermeability. Anesth Analg. 2006;103(1):156-61, https:// doi.org/10.1213/01.ane.0000221186.64599.78.

7. Ponikowski P, Voors AA, Anker SD, Bueno H, Cleland JGF, Coats AJS, et al. 2016 ESC Guidelines for the diagnosis and treatment of acute and chronic heart failure. Eur Heart J. 2016;37(27):2129-200, https://doi.org/10.1093/eurheartj/ehw128.

8. Orso D, Boaro G, Cassan E, Guglielmo N. Is morphine safe in acute decompensated heart failure? A systematic review of the literature. Eur J Intern Med. 2019;69(August):e8-10, https://doi.org/10.1016/j.ejim.2019.08.016.

9. Agewall S. Morphine in acute heart failure. J Thorac Dis. 2017;9(7):1851-4, https://doi.org/10.21037/jtd.2017.06.129.

10. Miró Ò, Gil V, Martín-Sánchez FJ, Herrero-Puente P, Jacob J, Mebazaa A, et al. Morphine Use in the ED and Outcomes of Patients With Acute Heart Failure. J Thorac Dis. 2017;9(9):821-32, https://doi.org/10.21037/jtd.2017. 08.22 .

11. Duarte GS, Nunes-Ferreira A, Rodrigues FB, Pinto FJ, Ferreira JJ, Costa J, et al. Morphine in acute coronary syndrome: Systematic review and meta-analysis. BMJ Open. 2019;9(3): 1-10, https://doi.org/10.1136/bmjopen-2018-025232. 
12. Feeney C, Ani C, Sharma N, Frohlich T. Morphine-Induced Cardiogenic Shock. Ann Pharmacother. 2011;45(6):e30, https://doi.org/10.1345/aph.1Q022.

13. Jones TL, Nakamura K, McCabe JM. Cardiogenic shock: evolving definitions and future directions in management. Open Hear. 2019;6(1):e000960, https://doi.org/10.1136/openhrt-2018-000960.

14. Polo L. Leczenie wstrząsu kardiogennego wikłającego zawał serca - nadal więcej pytań niż jednoznacznych odpowiedzi. Chor Serca Naczyń. 2019;16(3):188-96, https://doi.org/10. 5603/ChSiN.2019.0029. Polish.

15. Puymirat E, Fagon JY, Aegerter P, Diehl JL, Monnier A, Hauw-Berlemont $\mathrm{C}$, et al. Cardiogenic shock in intensive care units: evolution of prevalence, patient profile, management and outcomes, 1997-2012. Eur J Heart Fail. 2017;19(2): 192-200, https://doi.org/10.1002/ejhf.646.

16. Headrick JP, Pepe S, Peart JN. Non-Analgesic Effects of Opioids: Cardiovascular Effects of Opioids and their Receptor Systems. Curr Pharm Des. 2012;18(37):6090-100, https:/doi. org/10.2174/138161212803582360.

17. Darke S, Duflou J, Torok M. The health consequences of injecting tablet preparations: foreign body pulmonary embolization and pulmonary hypertension among deceased injecting drug users. Addiction. 2015;110(7):1144-51, https:// doi.org/10.1111/add.12930.

18. Marsch LA, Bickel WK, Badger GJ, Rathmell JP, Swedberg MDB, Jonzon B, et al. Effects of Infusion Rate of Intravenously Administered Morphine on Physiological, Psychomotor, and Self-Reported Measures in Humans. J Pharmacol Exp Ther. 2001;299(3):1056-65.
19. Kunecki M, Płazak W, Podolec P, Gołba KS. Wpływ endogennych mechanizmów kardioprotekcyjnych na uszkodzenie niedokrwienno-reperfuzyjne. Postepy Hig Med Dosw. 2017;71: 20-31, https://doi.org/10.5604/17322693.1228267. Polish

20. Behzadi M, Joukar S, Beik A. Opioids and Cardiac Arrhythmia: A Literature Review. Med Princ Pract. 2018;27(5): 401-14, https://doi.org/10.1159/000492616.

21. Elkalioubie A, Allorge D, Robriquet L, Wiart J-F, Garat A, Broly F, et al. Near-fatal tramadol cardiotoxicity in a CYP2D6 ultrarapid metabolizer. Eur J Clin Pharmacol. 201167(8): 855-8, https://doi.org/10.1007/s00228-011-1080-x.

22. Lusetti M, Licata M, Silingardi E, Reggiani Bonetti L, Palmiere C. Therapeutic and recreational methadone cardiotoxicity. J Forensic Leg Med. 2016;39:80-4, https://doi. org/10.1016/j.jflm.2016.01.016.

23. Hole LD, Larsen TH, Fossan KO, Limé F, Schjøtt J. Morphine enhances doxorubicin-induced cardiotoxicity in the rat. Cardiovasc Toxicol. 2014;14(3):251-9, https://doi.org/10.1007/ s12012-014-9249-z.

24. Boeuf B, Poirier V, Gauvin F, Guerguerian AM, Roy C, Farrell C, et al. Naloxone for shock. Cochrane Database Syst Rev. 2003;(4):CD004443, https://doi.org/10.1002/14651858.CD004443.

25. Perdreau E, Iriart X, Mouton J-B, Jalal Z, Thambo J-B. Cardiogenic shock due to acute tramadol intoxication. Cardiovasc Toxicol. 2015;15(1):100-3, https://doi.org/10.1007/ s12012-014-9262-2.

26. Gillard P, Laurent M. Dextropropoxyphene-induced cardiogenic shock: treatment with intra-aortic balloon pump and milrinone. Intensive Care Med. 1999;25(3):335, https://doi. org/10.1007/PL00003771.

This work is available in Open Access model and licensed under a Creative Commons Attribution-NonCommercial 3.0 Poland License - http://creativecommons.org/ licenses/by-nc/3.0/pl/deed.en. 